\title{
IMPLIKASI KEBIJ AKAN FORMULASI PENGGUNAAN ALOKASI DANA BAGI HASIL CUKAI TEMBAKAU TERHADAP PROGRAM PEMBINAAN LINGKUNGAN SOSIAL
}

\author{
Suteki \\ Fakultas Hukum Universitas Diponegoro \\ arjuna_teki@yahoo.com
}

\begin{abstract}
ABSTRAK
Analisis terhadap hubungan hukum dan kemiskinan tidak dapat dilepaskan dari adanya konsep atau model bekerjanya hukum dalam masyarakat. Bertitik tolak dari batasan model yang tidak dikemukakan oleh Seidman, dapat diketahui dalam peranan hukum dalam mengubah dan mengarahkan perilaku atau pola-pola tingkah laku pemegang peran, dalam hal ini adalah warga masyarakat. Apabila perubahan perilaku ini dapat dilaksanakan maka hukum dalam bekerjanya dapat berfungsi sebagai sarana untuk merekayasa masyarakat (a tool of social Engineering). Dengan demikian pada tingkatan tertentu diharapkan hukum dapat menanggulangi bahkan menghapuskan kemiskinan. Berdasarkan UU No. 39 Tahun 2007 tentang Cukai, pasal 66A ayat (1), salah satu tujuan bagi hasil cukai pembinaan industri, pembinaan lingkungan sosial. Pendapatan cukai tentu saja tidak lepas dari jerih payah para karyawan/buruh. Setiap hari sejak subuh para buruh/karyawan sudah berangkat kerja menuju brak-brak rokok untuk membuat lintingan batang per batang. Karena itu, pemerintah daerah perlu memperjuangkan konsep regulasi teknis untuk memikirkan nasib buruh/karyawan. Jika dilihat dari tingkat kesejahteraan, kehidupan para buruh tentu masih belum seluruhnya layak. Karena itu, pemerintah kabupaten perlu memprioritaskan nasib para buruh dalam regulasi di tingkat teknis dalam pengelolaan dana bagi hasil cukai tersebut. Melakukan perbaikan nasib buruh dengan cara: (1) pemberian beasiswa bagi putra-putri buruh, (2) memberikan tambahan penghasilan (tunjangan) bagi para pendidik yang mengelola lembaga pendidikan swasta yang kebanyakan berasal dari keluarga buruh, (3) membangun sarana dan prasarana pendidikan, (4) pemberian pelayanan hibah atau kredit lunak, (5) peningkatan jaminan kesehatan, (6) peningkatan sarana dan prasarana publik yang bermanfaat baik secara langsung atau tidak langsung terhadap produktivitas pabrik-pabrik penghasil cukai, serta (7) pemberian subsidi perumahan, dana rehab atau bedah rumah bagi para buruh yang tidak memiliki rumah atau memiliki rumah yang tidak layak huni.
\end{abstract}

\section{Kata Kunci: Cukai Tembakau; Kebijakan Formulasi}

\section{A. LATAR BELAKANG}

Hukum untuk manusia, bukan manusia untuk hukum. Melalui penalaran seperti ini, maka hukum itu bukan merupakan tujuan, akan tetapi hanya merupakan jembatan, yang akan membawa

kita untuk mencapai tujuan hidup sebagai negara

bangsa. Untuk itu kita harus mengetahui masyarakat yang bagaimana yang dicita-citakan 
oleh bangsa Indonesia baru kemudian kita dapat menentukan hukum yang bagaimana yang dapat membawa rakyat kita ke arah masyarakat yang dicita-citakan itu. Cita-cita bangsa Indonesia tidak lain adalah tujuan nasional yang tercantum dalam alinea ke-4 Pembukaan UUD 1945. Tujuan nasional tersebut adalah (1) melindungi segenap bangsa Indonesia dan seluruh tumpah darah Indonesia, (2) memajukan kesejahteraan umum, (3) mencerdaskan kehidupan bangsa dan (4) ikut melaksanakan ketertiban dunia yang berdasarkan kemerdekaan, perdamaian abadi dan keadilan sosial.

Sebagai negara hukum ${ }^{1}$, negara Indonesia dapat mendayagunakan hukum sebagai sarana untuk mewujudkan cita-cita nasional atau dalam bahasa kebijakan, hukum dapat digunakan sebagai instrumen kebijakan tertentu (law as an instrument of policy). Memajukan kesejahteraan umum (sosial)

1 Jimly Assiddiqie memerinci karaktristik negara hukum dengan menyebut 12 ciri. Karakteristik tersebut yaitu: (1) Supremasi hukum (Supremacy of Law); (2) Persamaan dalam Hukum (Equality before the Law); (3) Asas legalitas (Due Process of Law); (4) Pembatasan kekuasaan; (5) Organorgan Eksekutif Independen; (6) Peradilan Bebas dan Tidak Memihak; (7) Adanya Peradilan Tata Usaha Negara; (8) Peradilan Tata Negara (Constitutional Court); (9) Perlindungan Hak Asasi Manusia; (10) Bersifat Demokratis (Demecratische Rechtsstaat); (11) Berfungsi Sebagai Sarana Untuk Mewujudkan Tujuan Negera (Welfare Rechtsstaat) dan (12) Transparansi dan Kontrol Sosial. Lihat, Jimly Asshiddiqie, Konstitusi dan Konstitusionalisme Indonesia, Sekretariat Jenderal dan Kepaniteraan Mahkamah Konstitusi, Jakarta, 2006, hlm. 151-161. merupakan salah satu tujuan negara hukum Indonesia didirikan. Tujuan nasional ini seharusnya diterjemahkan ke dalam instrumen peraturan perundang-undangan di bawah UUD 1945. Hukum dalam wajahnya berupa sistem peraturan perundang-undangan inilah yang diharapkan mampu mewujudkan kesejahteraan umum (sosial). Untuk dapat mewujudkan kesejahteraan sosial, maka hukum harus dapat menciptakan keadilan, bukan hanya keadilan individual (baik keadilan legal, maupun keadilan komutatif), melainkan juga keadilan distributif atau dapat diterjemahkan lebih kongkret menjadi keadilan sosial.

Berdasarkan uraian di atas tampak jelas bahwa hukum dan keadilan sosial memiliki hubungan yang sangat erat dengan kesejahteraan sosial. Dalam UUD 1945, Kesejahteraan Sosial diatur dalam Pasal 33 dan 34. Dapat dikatakan bahwa kesejahteraan sosial menyangkut pemenuhan kebutuhan materiil yang harus diatur dalam organisasi dan sistem ekonomi yang berdasarkan kekeluargaan. Kesejahteraan sosial adalah sarana materiil yang harus dipenenuhi untuk mencapai rasa aman dan tenteram yang disebut keadilan sosial. Sedangkan keadilan sosial merupakan tujuan yang lebih tinggi daripada sekedar kesejahteraan. Keadilan merupakan condition sine qua non terciptanya ketertiban dan merupakan syarat utama berlangsungnya 
kehidupan masyarakat. Keadilan menjaga supaya tidak terjadi ketimpangan sehingga tercipta keseimbangan antara hak dan kewajiban, adanya keseimbangan antara kepentingan pribadi dan kepentingan sosial.

Melalui UU No. 39 Tahun 2007 tentang Cukai, negara sebenarnya ingin agar pelaksanaan UU ini juga dapat menciptakan kesejahteraan sosial. Hal ini dapat dibuktikan melalui isi dari konsiderans UU Cukai tersebut. UU Cukai disusun berdasarkan pertimbangan bahwa cukai sebagai pungutan negara yang dikenakan terhadap barangbarang tertentu yang mempunyai sifat atau karakteristik sesuai dengan undang-undang merupakan penerimaan negara guna mewujudkan kesejahteraan bangsa. Kesejahteraan bangsa menjadi tanggung jawab negara c.q. pemerintah, baik pemerintah pusat maupun pemerintah daerah. Instrumen otonomi daerah berusaha membagi tanggung jawab terhadap kewajiban untuk mewujudkan kesejahteraan rakyat oleh pemerintah pusat dengan pemerintah daerah. Salah satu cara untuk mendanai pembangunan di daerah adalah alokasi pendanaan dari pemerintah pusat yang diberikan kepada pemerintah daerah dalam bentuk Dana Alokasi Umum (DAU). Pengalokasian dana bagi hasil tembakau yang diatur dalam UU Cukai merupakan salah satu cara pemerintah pusat mendanai pembangunan di daerah melalui DAU untuk mewujudkan kesejahteraan sosial. Pasal 66A secara tegas menyatakan bahwa salah satu cara penggunaan alokasi DBHCHT adalah untuk melakukan pembinaan lingkungan sosial, maka berarti persoalan penaggulangan kemiskinan dapat menjadi salah satu sasaran program tersebut. Dalam hal ini hokum, melalui peraturan perundangundang sedang menjalani fungsinya sebagai sarana untuk melakukan rekayasa sosial (law as a tool of social engineering).

Kebijakan terkait Dana Bagi Hasil Cukai Hasil Tembakau (DBHCHT) tahun 2007 melalui UU Nomor 39 tahun 2007 tentang Cukai dan Putusan Mahkamah Konstitusi Nomor 54/PUU-VI/2008 tahun 2008, setiap tahunnya Pemerintah telah mengalokasikan dan menyalurkan DBHCHT sebesar 2\% (dua persen) dari penerimaan negara cukai hasil tembakau yang dibuat di Indonesia kepada provinsi Penghasil Cukai Hasil Tembakau dan Provinsi Penghasil Tembakau, yang selanjutnya oleh Provinsi Penerima DBHCHT bersangkutan dibagikan kepada provinsi/kabupaten/ kota di wilayahnya dengan komposisi 30\% (tiga puluh persen) untuk provinsi penghasil, 40\% (empat puluh persen) untuk kabupaten/kota daerah penghasil, dan 30\% (tiga puluh persen) untuk kabupaten / kota lainnya. 
DBHCHT yang dibagikan tersebut bersifat specific grant, di mana penggunaannya sudah diarahkan untuk mendanai kegiatan tertentu sebagaimana diatur dalam Pasal 66A UU Nomor 39 tahun 2007 ayat (1) yaitu untuk mendanai peningkatan kualitas bahan baku, pembinaan industri, pembinaan lingkungan sosial, sosialisasi ketentuan di bidang cukai, dan/atau pemberantasan barang kena cukai ilegal. Selanjutnya kelima kegiatan tersebut dirinci lebih detil menjadi 21 (dua puluh satu) sub jenis kegiatan sebagaimana diatur dalam PMK 84/PMK.07/2008 jo. PMK Nomor 20/PMK.07/2009 tentang Penggunaan DBHCHT dan Sanksi atas Penyalahgunaan DBHCHT.

Pengaturan penggunaan DBHCHT tersebut pada dasarnya merupakan bentuk sharing kewajiban Pemerintah Pusat kepada Pemerintah Daerah penerima DBHCHT guna mendukung pelaksanaan pencapaian tujuan pengenaan cukai hasil tembakau yaitu dalam rangka pengendalian dan pengawasan serta mitigasi terhadap dampak negatif yang ditimbulkan produk tembakau disamping juga dalam rangka optimalisasi penerimaan negara CHT sebagaimana dimaksud dalam ketentuan Pasal 2 UU Nomor 39 tahun 2007.

Dengan pengaturan kebijakan DBHCHT sebagaimana tersebut di atas, maka sudah seharusnya DBHCHT yang diberikan kepada daerah penerima digunakan sesuai peruntukannya.
Namun dalam prakteknya kondisi yang terjadi malah sebaliknya, masih ditemukannya berbagai kegiatan penggunaan DBHCHT yang tidak sesuai dengan peruntukannya. Berdasarkan hasil evaluasi yang dilakukan terhadap rencana kerja anggaran maupun realisasi penggunaan anggaran DBHCHT dari beberapa daerah penerima masih menunjukkan ketidaktepatan daerah dalam mengalokasikan kegiatan yang sesuai dengan ketentuan, seperti penggunaan DBHCHT dalam bidang kesehatan.

Masih ditemukan adanya kegiatan pengadaan sarana dan prasarana kesehatan yang tidak ada kaitannya langsung dengan penanganan penyakit akibat dampak asap rokok atau penempatan kegiatan DBHCHT untuk menangani penyakit menular, HIVIAIDS, Keluarga Berencana, dan sebagainya. Kondisi ini tentu berakibat tidak hanya terhadap ketidak tercapaian tujuan cukai hasil tembakau tersebut, namun juga berpotensi menyalahi ketentuan yang berlaku.

Dari hasil evaluasi yang dilakukan di beberapa daerah, ternyata kondisi ketidaktepatan dalam pengalokasian penggunaan DBHCHT tersebut hampir merata terjadi disemua daerah, dan salah satu penyebabnya adalah faktor kurangnya pemahaman unit/aparatur pelaksana di daerah dalam menterjemahkan aturan pelaksanaan penggunaan DBHCHT sebagaimana tertuang 
dalam PMK 84/PMK.07/2008 jo. PMK Nomor 20/PMK.07/2009, meskipun sosialisasi maupun konsultasi atas pemahaman aturan penggunaan ini sudah sering dilakukan oleh Pemerintah Pusat maupun Pemerintah Provinsi Penerima.

Pada tahun 2013 DBHCHT telah memasuki tahun kelima pelaksanaannya, berbagai macam tanggapan para pengelola dana DBHCHT di daerah terhadap muatan PMK telah didengar, disatu pihak ada yang menyatakan bahwa pengaturan dalam PMK sangat membatasi penggunaan, namun di pihak lain ada yang menginginkan pengaturan yang lebih rinci lagi. Dalam rangka mengatasi berbagai permasalahan tersebut terutama untuk menjawab berbagai persoalan penggunaan $\mathrm{DBHCHT}$ di bidang kesehatan, kami menyambut baik kehadiran buku "Pedoman Penggunaan Dana Bagi Hasil Cukai Hasil Tembakau (DBHCHT) dalam Bidang Kesehatan" yang diterbitkan oleh Kementerian Kesehatan bekerjasama dengan Kementerian Keuangan. Dengan kehadiran buku pedoman ini diharapkan dapat membantu daerah dalam menyusun dan merencanakan kegiatan DBHCHT di bidang kesehatan yang tepat sasaran dan sesuai dengan ketentuan sehingga diharapkan pada gilirannya DBH CHT yang diberikan dapat digunakan secara optimal sesuai dengan tujuannya.
Praktik penggunaan dana alokasi bagi hasil tembakau di beberapa daerah ditemukan beberapa variasi. Seperti yang dilaporkan oleh Tim Humas Provinsi Jawa Tengah, pengelolaan Dana Bagi Hasil cukai rokok untuk Jawa Tengah belum optimal, dari 52,196 M baru sekitar 3 M yang digunakan untuk peningkatan usaha pertanian. Pada tahun 2011 total alokasi Cukai hasil tembakau yang dikembalikan ke Provinsi dan kabupaten/kota sebesar 52,196 M, dengan perincian Kabupaten Kudus mendapatkan 17,2 M, provinsi 15,6 M, Kota Surakarta 1,2 M dan seluruh Kabupatenkota yang besarnya antara 450 juta sampai 878 juta. Pada tahun 2013 ini kenaikan DBHCT untuk Jawa Tengah mengalami penurunan yang cukup banyak, dari Rp 426 milyar pada tahun 2012 menjadi Rp 364 milyar untuk tahun 2013. Pembagian dana sebesar Rp 426 milyar tersebut adalah 30 \% (128 milyar) untuk Pemerintah Provinsi Jawa Tengah, dan $70 \%$ (298 milyar) sisanya dibagikan ke pada 35 Kabupaten/Kota secara proporsional. Sebesar 40\% dari 298 milyar (119 milyar) diberikan kepada 15 Kabupaten/Kota penghasil tembakau, 30\% (89 milyar) lainnya diberikan kepada 35 kabupaten/kota secara merata.

Menurut Wakil ketua komisi B DPRD Jawa Tengah Muhammad Haris alokasi penggunaan dana bagi hasil cukai untuk pemerintah provinsi 
belum diarahkan pada upaya peningkatan program pengentasan kemiskinan), di sisi lain produktifitas pertanian dan UMKM. Dari 15,6 M yang digunakan untuk mendorong potensi usaha kecil hanya kurang dari $3 \mathrm{M}$, selainya digunakan untuk kegiatan lain. Dalam Perubahan APBD 2013 hanya ada beberapa kegiatan yang berdampak langsung pada masyarkat misalnya pengembangan diversifikasi usaha dan sistem distribusi koperasi dan UMKM sebesar 845 juta, pengembangan SDM dan kelembagaan koperasi dan UMKM 714 juta. Masih banyak kegiatan yang terkesan untuk menghabiskan uang saja misalnya promosi bahaya rokok lewat komik, DVD, serta sarana-sarana lain yang sebenarnya tidak sesuai peruntukan dan tidak diperlukan masyarakat. Haris berharap adanya transparansi dari pemerintah provinsi tentang penggunaan alokasi bagi hasil cukai tembakau ini. Karena masih baru, maka perlu transparansi dan harus benar-benar manfaat tidak hanya menghabiskan anggaran.

\section{B. PERMASALAHAN}

Situasi dilematis akan dihadapi oleh pemerintah sebagai penyelenggara negara yang bertanggung jawab terhadap kesejahteraan rakyatnya. Di satu sisi, cukai rokok mempunyai posisi strategis untuk menyokong APBN (termasuk APBD) khususnya dapat digunakan untuk melakukan pembinaan lingkungan sosial (misalnya

dampak akibat rokok perlu dikendalikan. Dewasa ini kampanye anti rokok serta adanya peraturan di tingkat daerah yang membatasi masyarakat untuk merokok jelas merupakan upaya untuk mengendalikan dampak rokok bagi kesehatan masyarakat. Kesadaran terhadap bahaya rokok terus ditingkatkan namun harapan perolehan "uang" dari sistem industri rokok tetap pula didambakan oleh jutaan penduduk, termasuk oleh Pemda (APBD) di daerah produsen rokok dan tembakau. Keadaan demikian sering menggiring pada statemen yang menyatakan bahwa cukai rokok itu adalah "tax of sin".

Permasalahan yang perlu diajukan dalam penelitian ini adalah sebagai berikut:

1. Bagaimanakah kebijakan pengaturan (formulasi) penggunaan alokasi Dana Bagi Hasil Cukai Hasil Tembakau (DBHCHT) terkait dengan program pembinaan lingkungan sosial?

2. Apakah produk kebijakan pengaturan penggunaan alokasi DBHCHT mampu mengarahkan pemerintah daerah setempat untuk melaksanakan program pembinaan lingkungan dalam rangka pengentasan kemiskinan?

3. Bagaimana strategi yang ideal tentang penggunaan hukum sebagai sarana untuk 
mengentaskan kemiskinan melalui studi kasus pelaksanaan kebijakan pengaturan penggunaan alokasi DBHCHT?

\section{PEMBAHASAN}

Negara Indonesia adalah negara hukum, dengan demikian negara telah memiliki landasan yuridis yang kuat dalam peranannya melaksanakan pembangunan. Pancasila sebagai ideologi bangsa dan sebagai pandangan hidup telah memberikan arah dan tujuan bagi pembangunan yang diharapkan, yakni menuju keadilan sosial bagi seluruh rakyat Indonesia, dan pembangunan manusia Indonesia seutuhnya. Indonesia juga dapat diklasifikasikan sebagai negara kesejahteraan (welfare state) yang mempunyai kewajiban untuk menyelenggarakan kesejahteraan umum, yaitu mewujudkan keadilan sosial bagi seluruh rakyat Indonesia sebagaimana tercantukm dalam alinea ke-4 Pembukaan UUD Negara Republik Indonesia 1945, sebagai berikut:

“......negara melindungi segenap bangsa dan seluruh tumpah darah Indonesia dan untuk memajukan kesejahteraan umum, mencerdaskan kehidupan bangsa dan ikut memelihara perdamaian dunia...".

Pasal 27 ayat (2) UUD NRI 1945 menyebutkan bahwa tiap-tiap warga negara berhak atas pekerjaan dan penghidupan yang layak bagi kemanusiaan. Pasal ini memberikan pengertian bahwa pemerintah berkewajiban untuk mengupayakan agar setiap warga negara dapat hidup layak sesuai dengan harkat martabat manusia Indonesia, atau dengan kata lain pemerintah berkewajiban untuk menanggulangi atau mengentaskan kemiskinan.

Sehubungan dengan masalah kemiskinan, pada Pasal 34 UUD NRI 1945 secara eksplisit dinyatakan bahwa fakir miskin dan anak-anak terlantar dipelihara oleh negara. Mengingat bahwa tujuan dibentuknya negara Indonesia adalah untuk memajukan kesejahteraan umum, maka konsekuensinya negara atau pemerintah tidak dapat melepaskan tanggung jawabnya untuk menaggulangi kemiskinan. Dalam era pembangunan di segala bidang kehidupan, untuk mewujudkan kesejahteraan sosial, hukum diharapkan mampu difungsikan untuk mengatasi kemiskinan yang masih dialami oleh sebagian warga negara kita. Dalam hal ini, hukum dapat dijadikan sebagai alat atau sarana untuk mengadakan rekayasa sosial (as a tool of social engineering) dalam upaya mengentaskan rakyat dari kemiskinan. 


\section{C.1. Pengertian Hukum}

Masyarakat Indonesia mempunyai pendapat-pendapat tertentu mengenai hukum. Terdapat berbagai pengertian atau arti yang diberikan pada hukum, yang variasinya adalah sebagai berikut :

1) Hukum diartikan sebagai ilmu pengetahuan;

2) Hukum diartikan sebagai norma atau kaidah, yakni patokan tingkah laku yang diharapakan;

3) Hukum diartikan sebagai disiplin, yaitu sistem ajaran tentang kenyataan;

4) Hukum diartikan sebagai tata hukum yaitu hukum positif tertulis;

5) Hukum diartikan sebagai petugas atau pejabat;

6) Hukum diartikan sebagai keputusan pejabat atau penguasa;

7) Hukum diartikan sebagai proses pemerintahan;

8) Hukum diartikan sebagai perilaku yang teratur dan unik;

9) Hukum diartikan sebagai jalinan nilai-nilai.2

Pengertian hukumn yang diberikan tersebut, menunjukan cakupan hukum yang tidak terbatas pada pengertian hukum yang secara normatif ada dalam undanng-undang saja. Dalan hal ini penulis memilih pengertian hukum sebagai

2 . Soerjono Soekanto dan Mustafa Abdullah, Sosiologi Hukum Dalam Masyarakat, (Jakarta : Rajawali, 1982), halaman 37-39 patokan yang merupakan keputusan/kebijakan dari pejabat pemerintah dan bukan hanya merupakan hukum positif tertulis.

\section{C.2. Hakikat Kemiskinan}

\section{a. Pengertian Kemiskinan}

Menurut Jhon Friedman, kemiskinan diartikan sebagai kecilnya peluang untuk mengakumulasikan basis kekuatan sosial, yang meliputi hal-hal sebagai berikut :

(1) Modal produktif seperti tanah, perumahan, perlatan dan lainnya;

(2) Sumber-sumber keuangan seperti pendapatan dan fasilitas kredit;

(3) Organisasi sosial dan politik untuk mencapai kebutuhan bersama;

(4) Jaringan-jaringan sosial untuk memperoleh pekerjaan seperti barang-barang, pengetahuan, informasi, keterampilan dan lainnya. ${ }^{3}$

\section{b. Tolak ukur kemiskinan}

Pada tahun 1975 berdasarkan indeksindeks tertentu oleh UNESCO telah diperkirakan bahwa garis batas kemiskinan diukur dari pendapatan perkapita adalah berkisar pada US \$ 100 per tahun. Sedangkan mengenai tolak ukur garis kemiskinan, menurut Sayogo adalah jumlah kalori yang dikonsumsikan perkapita. Batas kemiskinan ditentukan pada tingkat 1700 kalori

\footnotetext{
3 Suara Merdeka, 20 Juni 1991, halaman VI
} 
sehari perkapita. Batas ini sudah berada di bawah kebutuhan normal orang Indonesia yang membutuhkan lebih dari 2000 kalori per hari. ${ }^{4}$

Menurut kesimpulan penelitian Pusat Studi Institut Teknologi Bandung pada tahun 1992, walaupun Indonesia memiliki kekayaan yang melimpah, akan tetapi kenyataan menunjukan bahwa sebanyak $61,6 \%$ rumah tangga petani di Indonesia tergolong miskin dengan kriteria pendapatan Rp.50.000.- (sekarang diperkirakan Rp $500.000,-)$ atau kurang per bulan per keluarga. ${ }^{5}$ Sedangkan menurut Alex Emyll, MSP (1992), kriteria bagi batas kemiskinan adalah pendapatan sebesar Rp.20.000.- atau kurang perbulan perorangan. ${ }^{6}$

Merujuk pada data Badan Pusat Statistik (BPS) Per Maret 2011, jumlah penduduk miskin sebesar 30,02 juta orang atau $12,49 \%$ dari total seluruh penduduk Indonesia. Jika dibandingkan data Maret 2010, di mana penduduk miskin adalah 31,02 juta orang atau $13,33 \%$, maka terjadi penurunan 1 juta orang dalam setahun. Jumlah penduduk miskin 30,02 juta jiwa yang berada dibawah garis kemiskinan adalah jumlah yang masih sangat besar, ini belum ditambahkan

4 Soemitro, Ronny H, Perspektif Sosial Dalam Pemahaman Masalah-Masalah Hukum, (Semarang, Agung Press, 1989), $5 \mathrm{lbid}$, halaman 63

${ }^{6}$ Suara Merdeka, 14 Agustus 1992, halaman IX dengan yang sedikit di atas garis kemiskinan atau near poor yang bisa mencapai jumlah yang sama. Tahun sebelumnya, jumlah warga yang tergolong near poor mencapai 29,38 juta. Near poor ini menurut BPS ukurannya adalah 1,2 kali dari garis kemiskinan.

Definisi miskin menurut versi amerika serikat yang melihat pada penghasilan tentu berbeda dengan definisi miskin versi Indonesia yang berpedoman pada kemampuan membiayai kehidupannya. Jika tolok ukur miskin menurut versi Amerika adalah mereka yang berpenghasilan dibawah US \$ 30 per hari atau setara Rp 270.000, per hari ( Rp 8.100.000,- perbulan /kurs Rp. 9000 per US \$ ) maka dapat dikatakan PNS Indonesia masuk dalam katagori miskin. Namun, pendekatan kemiskinan di Indonesia dengan tolok ukur pengeluaran sebesar Rp. 233.740 per bulan ( Equivalen US \$ 25, 97 per bulan ) tentunya tidak dapat dibandingkan dengan standar kehidupan di Amerika Serikat.

Menurut BPS (2007), keluarga yang sama sekali tidak mempunyai kemampuan untuk memenuhi kebutuhan pokok atau orang yang mempunyai sumber mata pencaharian akan tetapi tidak dapat memenuhi kebutuhan keluarga yang 
layak bagi kemanusiaan dengan ciri-ciri atau kriteria sebagai berikut :

(i) Pembelanjaan rendah atau berada di bawah garis kemiskinan, yaitu kurang dari Rp.175.324 untuk masyarakat perkotaan, dan Rp.131.256 untuk masyarakat pedesaan per orang per bulan di luar kebutuhan non pangan;

(ii) Tingkat pendidikan pada umumnya rendah dan tidak ada keterampilan;

(iii) Tidak memiliki tempat tinggal yang layak huni, termasuk tidak memiliki MCK;

(iv) Pemilikan harta sangat terbatas jumlah atau nilainya;

(v) Hubungan sosial terbatas, belum banyak terlibat dalam kegiatan kemasyarakatan; dan

(vi) Akses informasi (koran, radio, televisi, dan internet) terbatas.

Menurut Sajogyo (1977), garis kemiskinan berdasarkan kebutuhan minimum rumah tangga adalah senilai $2.140 \mathrm{~kg}$ beras setiap orang per tahun di pedesaan dan $360 \mathrm{~kg}$ beras setiap orang per tahun di daerah kota. Penetapan garis kemiskinan ini yang setara dengan nilai beras dimaksudkan ini untuk dapat membandingkan tingkat hidup antar waktu dan perbedaan harga kebutuhan pokok antar wilayah. Pendapat Sajogyo ini pada masa berikutnya mendapat kritikan dari Both dan Sundrum, karena dalam kenyataannya beras tidak merupakan bahan kebutuhan pokok penduduk pedesaan yang miskin terutama di Pulau Jawa.

\section{c. Jenis Kemiskinan}

Belum ada cara yang benar-benar tepat untuk mendefinisikan kelompok miskin. Alternatif yang banyak digunakan adalah membedakan kemiskinan relatif dan kemiskinan absolut. Kemiskinan absolut mendasarkan pada suatu jumlah minimum tertentu untuk tingkat hidup subsisten. Batasan jumlah minimum inipun masih kabur, karena faktor yang membentuk minimalitas tersebut bersifat relatif subyektif dan sangat dipengaruhi oleh kodisi-kondisi ekonomi suatu negara. Dengan demikian makan akan muncul konsep yang berlawanan yaitu adanya kemiskinan yang relatif. Kemiskinan relatif mempunyai dasar batas minimum kemiskinan yang tidak tetap. Batasa kemiskinann yang ditetapkan akan terus berubah yang secara ideal akan meningkat. Hal ini disebabkan karena adamnya dampak pertumbuhan dan harapan yang terus berkembang, sementara pertumbuhan itu sendiri diragukan perembesannya ( efek tetesnya) bagi kelompok miskin.?

Para ahli kependudukan membagi tingkat kemiskinan menjadi dua, yaitu :

\footnotetext{
7 Suara merdeka, 14 Agustus 1991, halaman VI
} 
(1) Kemiskinan biasa, dimana penghasilan masih cukup untuk menjamin kebutuhan primernya, yaitu cukup untuk makan meskipun hannya ditahun-tahun yang normal, artinya dtahun itu tidak terjadi kemarau yang terlalu panjang ataupun ada bencana alam lainnya. Namun pada saat-saat sulit misalnya pada paceklik, dalam kemiskinan biasa seseorang tidak dapat memenuhi kebutuhan pokoknya secara wajar.

(2) Kemiskinan luarbiasa atau kemelaratan. Dalam hal ini penghasilan untuk menjamin kebutuhan primernya tidak cukup. Meskipun tidak ada bencana alam mauoun kemarau yang terlalu panjang. Untuk kebutuhan makan saja tidak mencukupi baik dari segi kuantitas maupun dari segi kualitas. ${ }^{8}$

\section{d. Sebab-sebab timbulnya kemiskinan}

Gunnar Myrdal mengajukan konsepsi hubungan kausal sirkuler yang kumulatif sebagai landasan untuk menjelaskan terjadinya ketidak merataan ekonomi nasioanal maupun internasional. Konsepsi Gunnar Myrdal didasarkan pada konsepsi lingkaran tak berujung pangkal (Vicious Circle) C.E.A Winslow. Selanjutnya dikemukakan bahwa kemiskinan dan penyakit membentuk lingkaran kemiskinan yang tak berujung pangkal. Orangorang menjadi sakit karena merka miskin. Mereka

${ }^{8}$ Soemitro, Ronny H, Studi Hukum dan Kemiskinan, (Semarang : Tugu Muda, 1989), halaman 30-31. menjadi miskin karena mereka sakit dan mereka semakin sakit karena mereka semakian miskin. Pernyatan Winslow ini adalah suatu pernyataan proses yang sirkuler dan komulatif yang terus menerus menurun ketingkat yang lebih rendah yaitu di mana satu faktor negatif menjalankan dua pernaan sekaligus yaitu menjadi sebab dan akibat dari faktor-faktor negatif lainnya. ${ }^{9}$

Menurut Lampman, terdapat tiga penyebab kemiskinan yaitu:

(1) Faktor resiko dari bekerjanya sistem ekonomi dan sistem pembangunan yang sedang dilaksanakan;

(2) Faktor batasan sosial yang terjadi karena adanya rintangan-rintangan penyempitan budaya kemiskinan dan lingkaran setan kemiskinan (vicious circle);

(3) Faktor-faktor perbedaan individu, yaitu karena adanya perbedaan dan ketidak merataan distribusi pendapatan diantara waraga masyarakat. Kenyataan menunjukan bahwa diantara warga masyarakat terdapat jurang pemisah anatara mereka yang berpenghasilan tinggi dan para buruh petani yang hannya berpenghasilan rendah. ${ }^{10}$

\footnotetext{
9 Soemitro, Ronny H, Studi Hukum dan Kemiskinan, (Semarang: Tugu Muda, 1989), halaman 45.

${ }^{10}$ Suara Merdeka, 14 Agustus 1992, halaman VI.
} 
Sedangkan Sadono Sukirno lebih cenderung menyatakan bahwa dualisme teknologi telah memperkukuh keadaan kemiskinan yang terdapat dinegara-negara berkembang, termasuk didalamnya Indonesia. Lebih lanjut dikatakan bahwa akhir-akhir ini disadari pula suatu implikasi yang tidak menguntungkan dari adanya dualisme teknologi. Kegiatan-kegiatan disektor pada umumnya mengalami perkembangan yang jauh lebih cepat dari pada sektor tradisional. Dengan demikian jurang tingkat kesejahteraan di antara kedua sektor tersebut makin lamamakin bertambah lebar. Sehingga walaupun dicita-citakan bahwa pembangunan bertujuan untuk meningkatkan kesejahteraan seluruh masyarakat, pada kenyataannya manfaat pembangunan terutama dinikmati hannya oleh golongan kecil penduduk di negara berkembang. Sebagaimana telah secara umum disadari bahwa jurang pemisah tingkat pendatan diantara golongan kaya dan miskin telah menjadi bertambah lebar. Dari pernyataan Sadono Sukirno ini dapat dikatakan jurang pemisah yang semakain melebar tersebut pada akhirnya akan membuat golongan masyarakat berpenghasilan rendah semakin sulit untuk beradaptasi dengan pembanguan teknologi yang semakin pesat. Dari sini kemiskinan diperkirakan akan muncul. ${ }^{11}$

11 Sukirno, Sadono, Ekonomi Pembanguan, (Jakarta, Bima
Di sisi lain Satjipto Raharjo, berpendapat, bahwa kemiskinan sekarang bukan disebabkan oleh faktor individual atau alam, melainkan disebabkan oleh proses-proses serta institusi yang terdapat dalam masyarakat. Hukum dapat dimasukan dalam institusi tersebut disamaping institusi-institusi yang lain. Hal ini dapat dimengerti karena di dalam negara yang berdasarkan hukum, maka warga negara yang ingin meninggkatakan kesejahtereaan harus berhadapan dengan hukum. Dengan demikian, mereka tidak dapat bertindak melalui dan mengiluti proses alami, melainkan dituntut untuk dilakukan melalui jalur hukum yang telah ditetapkan. Dalam hal ini hukum dapat menjadi penghambat atau kendala pertumbuhan ekonomi yang selanjutnya akan menimbulakan kemiskinan. Misalnya tindakan yang secara ekonomi adalah sah untuk dilakukan, tetapi oleh hukum dapat dimungkinkan dan dinyatakan dilarang, atau untuk melakukannya harus ditempuh melalui prosedur hukum tertentu. 12

\section{C.3. Fungsi Hukum}

Hoebel berpendapat bahwa ada empat fungsi dasar hukum yaitu :

Grafika, 1985), halaman 217.

12 Rahardjo, Satjipto, "Memikirkan Hubungan Hukum dan Kemiskinan", Gema Keadilan, No.1 Tahun ke 15;1991, hal aman 21 
a. Menetapkan hubungan-hubungan antar anggota masyarakat, dengan menunjukan jenis-jenis tingkah laku apa yang diperkenankan dan apa pula yang dilaranga;

b. Menentukan pembegian kekuasaan dan mencari siapa saja yang boleh melakukan paksaaan serta siapakah yang harus menaatinya dan sekaligus memilih sanksisanksinya yang tepat dan efektif;

c. Menyelesaikan sengketa;

d. Memelihara kemampuan masyarakat untuk menyesuaikan diri dengan keadaan kehidupan yang berubah-ubah, yaitu dengan merumuskan kembali hubungan yang esensial antara anggota-anggota masyarakat. ${ }^{13}$

Menuerut Profesor Peters, terdapat tiga perspektif dari fungsi hukum didalam masyarakat, yaitu :

a. Perspektif pertama adalah perspektif kontrol sosial (social control). Tinjauan yang demikian ini dapat disebut sebagai tinjauan dari sudut pandang seseorang polisi terhadap hukum (the policeman view the law).

b. Perspektif kedua dari fungsi hukum didalam masyarakat adalah perspektif social engineering yang merupakan tinjauan yang dipergunakan para pejabat (the official

${ }^{13}$ Warassih, Esmi, "Peranan Hukum dan Fungsi-fumngsinya", Masalah - masalah Hukum, No.5 - 1991, halaman 6. perspektif of the law) dan oleh karena pusat perhatiaanya adalah apa yang diperbuat pejabat atau penguasa maka tinjauan ini kerpakali disebut sebagai the technocrat's view of the law.

c. Perspektif ketiga adalah perspektif emansipasi masyarakat dari hukum. Perspektif ini merupakan tinjauan dari bawah terhadap hukum (the bottom's up view the law). Dengan perspektif ini ditinjau kemungkinankemungkinan dan kemampuan hukum sebagai sarana untuk menampung semua aspirasi masyarakat. ${ }^{14}$

Sesuai dengan tujan penelitian ini, maka yang perlu unutk dijelaskan adalah fungsi hukum dalam perspektif social engineering atau penggunaan hukum sebagai sarana untuk mengubah masyarakat. Salah satu fungsi hukum adalah sebagai alat untuk mengubah masyarakat, dalam arti bahwa hukum sangat mungkin digunakan sebagai alat oleh pelopor perubah (agent of change). Agent of change atau pelopor perubahan adalah seorang atau kelompok orang yang mendapat kepercayaan dari masyarakar untuk memimpin satu atau lebih lembaga-lembaga kemasyarakatan. Pelopor perubahan memimpin

${ }^{14}$ Soemitro, Ronny H, Studi Hukum dan Masyarakat, (Bandung, Alumni, 1985), halaman 10-11. 
masyarakat dalam mengubah sistem sosial dan dalam menjalankan hal itu langsung tersangkut dengan tekanan-tekanan untuk melakukan perubahan. Setiap perubahan sosial yang dikehendaki atau yang direncanakan, selalu berada di bawah pengendalian serta pengawasan pelopor perubahan tersebut. Oleh karena itu cara-cara untuk mempengaruhi masyarakat dengan sistemsistem yang direncanakan dan diatur lebih dahulu dinamakan social engineering atau social planning. 15

Kaidah-kaidah hukum sebagai alat untuk mengubah masyarakat mempunyai peranan penting terutama dalam perubahan-perubahan yang direncanakan (intended change atau planed change). Dengan perubahan yang dikehendaki dan direncanakan tersebut, dimaksudkan sebagai suatu perubahan yang dikehendaki dan direncanakan oleh warga-warga masyarakat yang berperan sebagai pelopor masyarakat. Dalam masyarakatmasyarakat yang sudah kompleks dimana birokrasi memegang peranan penting dalam tindakantindakan sosial, perubahan-perubahan tersebut harus mempinyai dasar hukum untuk sahnya. Legalitas dari perubahan tersebut sangat penting artinya. Kaidah-kaidah hukum yang telah terbentuk, dapamerupakan alat yang ampuh untuk

${ }^{15}$ Soekanto, Soerjono, Pokok-pokok Sosiologi Hukum, (jakarta : Rajawali, 1986), halaman 107. mengadakan perubahan-perubahan sosial, walaupun secara tidak langsung. Dengan demikan apabila pemerintah ingin membentuk badan-badan yang berfungsi untuk mengubah masyarakat secara terencana, maka hukum diperlukan untuk membentuk badan tersebut serta untuk menentukan dan membatasi kekuasaannya. Sampai di sini sudah terungkap bahwa kaidah hukum dapat mendorong terjadinya perubahanperubahan sosial yang membentuk badan-badan yang secara langsung berpengaruh terhadap perkembangan di bidang sosial, politik, bahkan di bidang ekonomi.16

Dalam hal penggunaan hukum sebagai alat untuk mengubah masyarakat, maka hukum tersebut harus disesuaikan dengan anggapananggapan masyarakat apabila suatu hasil positif hendak dicapai. Dengan pernyataan ini maka yang perlu dilakukan pertama adalah menelaah bagaimana anggapan-anggapan masyarakat tentang hukum. Artinya, apakah pada suatu saat fokus masyarakat tertuju pada hukum atau tidak. Kedua, perlu disoroti bagian-bagian manakah dari suatu sistem yang paling dihargai oleh sebagian terbesar masyarakat pada suatu saat. Hal-hal inilah secara minimal harus dipertimbangkan. ${ }^{17}$

\footnotetext{
16 Ibid, halaman 110-111.
}

17 Ibid, halaman 116. 
Di samping ada beberapa hal yang perlu diperhatikan, yaitu anggapan masyarakat terhadap hukum dan bagian yang paling mendapat penghargaan masyarakat, terdapat beberapa kondisi yang harus mendasari suatu sistem hukum agar dapat dipakai sebagai alat untuk mengubah masyarakat (a tool of socisl enginering). Kondisikondisi tersebut adalah:

1. Hukum merupakan aturan-aturan umum yang tetap; jadi bukan merupakan aturan yang bersifat ad hoc;

2. Hukum tersebut harus jelas bagi dan diketahui oleh warga-warga masyarakat yang kepentingannya diatur oleh hukum tersebut;

3. Sebaiknya dihindari penerapan peraturanperaturan yang bersifat retroaktif;

4. Hukum tersebut harus dimengerti oleh umum;

5. Tidak ada peraturan-peraturan yang bertentangan;

6. Pembentukan hukum harus memperhatiakan kemampuan para warga masyarakat untuk mematuhi hukum tersebut;

7. Perlu dihindarkan terlalu banyaknya, perubahan-perubahan hukum, oleh karena warga-warga masyarakat dapat kehilangan ukuran dan pegangan bagi kegiatannya;
8. Adanya korelasi antara hukum dengan pelaksanaan atau penerapan hukum tersebut. ${ }^{18}$

Pada kebanyakan masyarakat sistem hukumnya banyak berpengaruh dan mendukung lembaga-lembaga sosial yang telah ada. Suatu pemerintah yang berkuasa dapat menggunakan hukum untuk merubah lembaga-lembaga sosial yang berupa pola-pola tingkah laku yang telah ada. Perubahan lembaga-lembaga yang berupa polapola tingkah laku tersebut diharapkan hukum sampai sampai tingkatan tertentu mampu mengarahkan tingkah laku tersebut hingga dapat berfungsi sebagai sarana untuk menghapuskan atau mengurangi kemiskinan. Hal ini tergantung dari dua faktor yaitu: pertama, penguasa harus berkemauan keras untuk mengadakan perubahanperubahan dan kedua, perbahan-perubahan itu hanya dapat terjadi bila tidak terdapat perbedaan pendapat antara para penguasa politik dengan kelompok pengendali ekonomi termasuk juga masyarakat yang berekonomi kuat. ${ }^{19}$

Dalam rangka pembangunan di daerah, perlu terus dikembangkan dan ditingkatkan prakarsa dan partisipasi masyarakat termasuk di dalamnya lembaga swadaya masyarakat, serta peranan pemerintah daerah dalam pembangunan.

\footnotetext{
18 Ibid, halaman 130.

19 Soemitro, Ronny H, Permasalahan Hukum di Dalam Masyarakat, (Bandunng : Alumni,1984), halaman 73
} 
Untuk itu ditingkatkan kemampuan pengelolaan pembangunan dari seluruh aparatur pemerintah di daerah sekaligus dalam rangka mewujudkan otonomi daerah yang lebih nyata dan bertanggung jawab. Pemerintah daerah yang dimaksud termasuk di dalamnya adalah Pemerintah Provinsi, Pemerintah Kabupaten/Kota. Sejalan dengan pemikiran ini, perlu terus dibangun dan ditingkatkan kemapuan daerah untuk membangun antara lain dengan menghimpun dana secara wajar dan tertib termasuk penggalian dana baru yang tidak bertentangan dengan kepentingan nasional.

Sebagian besar kantong-kantong kemiskinan berada di pedesaan. Oleh karena itu, usaha untuk mengentaskan kemiskinan seharusnya diupayakan dari pedesaan. Upaya tersebut antara lain ditempuh melalui pembentukan lembagalembaga swadaya masyarakat untuk menghimpun dana pembangunan daerah pedesaan khususnya. Pembangunan yang meliputi segala bidang kehidupan, tidak dapat dilakukan hanya oleh sebagian masyarakat, melainkan melibatkan partisipasi seluruh rakyat.

Pengesahan UU Cukai ini akan semakin memperkuat posisi cukai sebagai sumber pundi keuangan negara. Cukai menempati urutan ketiga sumber pendapatan negara. Dua besar masih didominasi hasil ekspor baik produk minyak dan gas (migas) maupun non migas serta berbagai jenis pajak. "Pada 2006, jumlah cukai mencapai Rp 38,5 triliun. Tahun ini meningkat Rp 3,5 triliun menjadi Rp 42 triliun. Ketentuan tentang bagi hasil tembakau dapat disimak pada Pasal 66 UU Cukai.

\section{Pasal 66A}

(1) Penerimaan negara dari cukai hasil tembakau yang dibuat di Indonesia dibagikan kepada provinsi penghasil cukai hasil tembakau sebesar 2 persen yang digunakan untuk mendanai peningkatan kualitas bahan baku, pembinaan industri, pembinaan lingkungan sosial, sosialisasi ketentuan di bidang cukai, dan/atau pemberantasan barang kena cukai ilegal.

(4) Pembagian dana bagi hasil cukai hasil tembakau dilakukan dengan persetujuan Menteri, dengan komposisi 30 persen untuk provinsi penghasil, 40 persen untuk kabupaten/kota daerah penghasil, dan 30 persen untuk kabupaten/kota lainnya.

\section{Pasal 66D}

(1) Atas penyalahgunaan alokasi dana bagi hasil cukai hasil tembakau dapat diberikan sanksi berupa penangguhan sampai dengan penghentian penyaluran dana bagi hasil cukai hasil tembakau yang dibuat di Indonesia.

(2) Ketentuan lebih lanjut mengenai sanksi atas penyalahgunaan alokasi dana bagi hasil cukai hasil tembakau diatur dengan peraturan menteri. 
Ada satu poin baru yang cukup menarik, yakni dana bagi hasil untuk daerah penghasil tembakau. Ketentuan tersebut tertuang dalam Pasal 66A, 66B, 66C, dan 66D. Penerimaan negara dari cukai hasil tembakau akan dibagikan kepada provinsi penghasilnya sebesar 2 persen. Selanjutnya, realisasi dana segitu dibagikan kepada provinsi itu sendiri sebesar 30 persen, kota/kabupaten penghasil sebesar 40 persen ${ }^{20}$, dan kota/kabupaten lainnya yang masih seprovinsi sebesar 30 persen. Caranya, lewat pemindahbukuan dari rekening kas umum negara ke rekening kas umum provinsi dan rekening kas umum kota/kabupaten. Tentu saja bagi-bagi hasil ini atas persetujuan Menteri Keuangan. Bagi hasil tersebut muncul dalam Dana Alokasi Umum (DAU) pada Anggaran Pendapatan dan Belanja Daerah (APBD). Setiap daerah juga harus siap. Ini berdampak peralihan belanja dari pusat ke daerah. Masalahnya, ada beberapa kendala. Misalnya persiapan pencairan APBD. Pemerintah juga perlu mempersiapkan instrumen aturan yang memperlancar belanja daerah.

\footnotetext{
${ }^{20}$ Daerah produsen cukai rokok yang meliputi 8 kabupaten yaitu Kabupaten Kudus, Kota Surabaya, Kota Kediri, Kota Malang, Kabupaten Malang, Kabupaten Kediri, dan Kabupaten Pasuruan.
}

Berdasarkan Pasal 66A ayat (1), bagi hasil ini untuk bermacam tujuan yang sudah ditentukan, di antaranya untuk

(1) mendanai peningkatan kualitas bahan baku,

(2) pembinaan industri, pembinaan lingkungan sosial,

(3) sosialisasi ketentuan di bidang cukai, serta

(4) pemberantasan Barang Kena Cukai (BKC) ilegal.

Situasi sulit akan dihadapi oleh pemerintah sebagai penyelenggara negara yang bertanggung jawab terhadap kesejahteraan rakyatnya. Di satu sisi, cukai rokok mempunyai posisi strategis untuk menyokong APBN (termasuk APBD), di sisi lain dampak akibat rokok perlu dikendalikan. Dewasa ini kampanye anti rokok serta adanya peraturan di tingkat daerah yang membatasi masyarakat untuk merokok jelas merupakan upaya untuk mengendalikan dampak rokok bagi kesehatan masyarakat. Kesadaran terhadap bahaya rokok terus ditingkatkan namun harapan perolehan "uang" dari sistem industri rokok tetap pula didambakan oleh jutaan penduduk, termasuk oleh Pemda (APBD) di daerah produsen rokok dan tembakau. Masyarakat kita belum sejahtera. Kelangkaan lapangan kerja di luar sistem produksi rokok memaksa penduduk (buruh, petani) sekaligus Pemda untuk melanggengkan industri rokok yang 
dipenuhi situasi dilematis ini. Rokok terbuat dari lintingan tembakau (Nicotania Tobacum). Sampai tahun 1920-an rokok dikenal luas sebagai penenang yang dapat membebaskan perokok dari kecemasan atau stress. Hal tersebut diperkuat oleh dukungan para dokter pada waktu itu. Baru setelah 70 tahun kemudian, pengaruh negatif rokok diketahui. Meskipun ditemui situasi yang dilematis, namun, upaya untuk keluar dari situasi dilematis ini tetap harus dilakukan baik oleh pemerintah maupun rakyat.

Setiap orang saya kira tahu betapa bahayanya rokok bagi kesehatan manusia. Bukan saja berbahaya bagi penghisapnya tetapi juga berbahaya bagi orang-rang yang berada di sekitarnya (perokok pasif). Memang belum ada studi atau penelitian yang menyajikan perbandingan antara biaya kesehatan yang dikeluarkan untuk membiayai penyakit akibat merokok dengan besarnya dana APBN maupun APBD yang diterima oleh Pemerintah. Imbangkah antara pendapatan dari rokok dengan bahaya akibat rokok bagi kesehatan manusia? Siapakah yang peduli dengan masalah ini? Mampukah cukai tembakau dapat secara signifikan menurunkan produksi dan konsumsi rokok? Apa akibatnya bila seluruh penduduk negeri ini tidak menghisap rokok? Bila produksi rokok berhenti, bagaimana nasib para pekerja di pabrik rokok? Bagaimana pula nasib petani tembakau? Bagaimana pula nasib APBN dan APBD? Vicious circle. Kita sulit untuk menentukan dari mana kita harus mengatasi masalah dilematis ini.

Upaya sistematis dapat dilakukan oleh pemerintah dan masyarakat untuk mengatasi problematika di bidang industri rokok. Upaya-upaya tersebut antara lain:

1. Secara terencana pemerintah harus mulai mengarahkan alih tanaman bagi petani tembakau melalui program intensifikasi pertanian yang handal.

2. Negara (c.q. Pemerintah Pusat dan Daerah) secara terencana harus mengurangi ketergantungan APBN pada sumber cukai tembakau.

3. Petani harus mulai mengganti tanaman tembakau dengan tanaman lain sesuai dengan program intensifikasi pertanian pemerintah.

4. Penggunaan dana alokasi umum yang berasal dari DBH cukai tembakau harus tepat sasaran dan diarahkan pada rencana penurunan produksi rokok dengan mengalihkan pada produksi barang lainnya seperti kerajinan tangan, elektronik dll.

5. Pemerintah perlu merumuskan New Deal sebagai suatu program yang mereformasi sistem keuangan dan perbankan dan membuat banyak program untuk membantu para 
penganggur, melaksanakan jaminan sosial brak-brak rokok untuk membuat lintingan batang yang meliputi bantuan untuk para penganggur, per batang. Karena itu, pemerintah daerah perlu jaminan untuk orang usia lanjut, orang cacat memperjuangkan konsep regulasi teknis untuk dan sebagainya. Di dalamnya termasuk program Agricultural Adjusment Administration Act (AAA) untuk memberikan subsidi kepada petani dan dapat memberikan Bantuan Langsung Tunai (BLT) kepada orang miskin.

6. Melakukan perbaikan nasib buruh dengan cara: (1) pemberian beasiswa bagi putra-putri buruh, (2) memberikan tambahan penghasilan (tunjangan) bagi para pendidik yang mengelola lembaga pendidikan swasta yang kebanyakan berasal dari keluarga buruh, (3) membangun sarana dan prasarana pendidikan, (4) pemberian pelayanan hibah atau kredit lunak, (5) peningkatan jaminan kesehatan, (6) peningkatan sarana dan prasarana publik yang bermanfaat baik secara langsung atau tidak langsung terhadap produktivitas pabrik-pabrik penghasil cukai, serta (7) pemberian subsidi perumahan, dana rehab atau bedah rumah bagi para buruh yang tidak memiliki rumah atau memiliki rumah yang tidak layak huni.

Sebagaimana kita ketahui, pendapatan cukai tentu saja tidak lepas dari jerih payah para karyawan/buruh. Setiap hari sejak subuh para buruh/karyawan sudah berangkat kerja menuju memikirkan nasib buruh/karyawan. Jika dilihat dari tingkat kesejahteraan, kehidupan para buruh tentu masih belum seluruhnya layak. Karena itu, pemerintah kabupaten perlu memprioritaskan nasib para buruh dalam regulasi di tingkat teknis dalam pengelolaan dana bagi hasil cukai tersebut.

Untuk mengakhiri perbincangan ini perlu saya sampaikan bahwa pada nilai keadilan sosial hendaknya menjadi visi utama dalam pengelolaan dana bagi hasil cukai tembakau. Kendati hukum memang seharusnya menjadi alat legitimasi kebijakan, tetapi pada suatu saat kita harus berani melakukan "rule breaking" sehingga kita menjadi lebih kreatif dalam penegakkan hukum agar tujuan sejati hukum untuk menciptakan kesejahteraan/kebahagiaan tercapai. Kita sadar betul bahwa pada waktu sakit, orang kadang terpaksa menelan pil pahit untuk menyembuhkan penyakitnya. Untuk tujuan ke depan demi kesejahteraan umat manusia secara bertahap masyakat Jawa Tengah harus melepaskan diri dari ketergantungannya terhadap industri rokok yang jelas berbahaya bagi kesehatan umat manusia. 


\section{C.4. Hubungan Hukum dan Kemiskinan}

Dalam era industrialisasi sebagai ciri dunia ketiga, pada kenyatannya kemiskinan masih merupakan sosok yang nyata yang meliputi bagian besar penduduknya. Kemiskinan dapat terjadi disebabkan oleh karena lembaga-lembaga yang membentuk masyarakat yaitu pada tingkah laku yang berulang-ulang dari anggota masyarakatnya. Peraturan-peraturan hukum menetapkan normanorma tingkah laku. Peraturan tersebut mengatur tentang segala sesuatu yang diperbolehkan dan sekaligus membatasi, di samping juga menentukan norma-norma yang tidak boleh dilakukan warga masyarakat yang dikenai sasaran peraturan tersebut.

Lebih lanjut Seidman berpendapat, bila para penguasa di dunia ketiga hendak merubah lembaga-lembaga masyarakat mereka harus menggunakan sistem hukum untuk menetapkan norma-norma tingkah laku baru dengan menghormati lembaga-lembaga yang dmaksud dan mengusahakan terbentuknya sarana-sarana untuk mendorong tingkah laku yang sesuai. Lembagalembaga sosial, politik dan ekonomi di dunia ketiga dapat menghasilkan kemiskinan untuk menggunakan sistem hukum guna mengubah lembaga-lembaga itu memerlukan sebuah modal yang menjelaskan bagaimana hukum memberikan pengaruh terhadap tingkah laku-tingkah laku dan kemudian menggunakan pengetahuan itu untuk mendorong terciptanaya tingkah laku baru ayng mengurangi kemiskinan. ${ }^{21}$

Sistem hukum dapat menimbulkan atau mempengaruhi tingkah laku warga masyarakat. Pernan ini hanya dapat dilakukan dengan persyaratan bahwa peraturan hukum ditetapkan berdasarkan kehendak sebagai variabel bebas (independent variabel). Sedangkan faktorfaktor yang mempengaruhi pemilihan dan pengidentifikasian sistem hukum dan sebagai variabel operasional atau penjelasan. Bekerjanya hukum dalam masyarakat melibatkan beberapa unsur atau aspek yang saling memiliki keterkaitan sebagai suatu sistem. Beberapa aspek tersebut yaitu: Lembaga Pembuat Hukum (Law Making Institutions), Lembaga Penerap Sanksi (Sanction Activity Institutions), Pemegang Peran (Role Occupant) serta Kekuatan Sosietal Personal (Societal Personal Force), Budaya Hukum (Legal

${ }^{21}$ Soemitro, Ronny H, Studi Hukum dan Kemiskinan, (Semarang : Tugu Muda, 1989), halaman 9. 
Culture) ${ }^{22}$ serta unsur-unsur Umpan Balik (Feed Back) dari proses bekerjanya hukum yang sedang berjalan. Seidman juga menggambarkan model bekerjanya hukum dalam masyarakat untuk mengarahkan laku pemegang peran dengan diagram berikut :

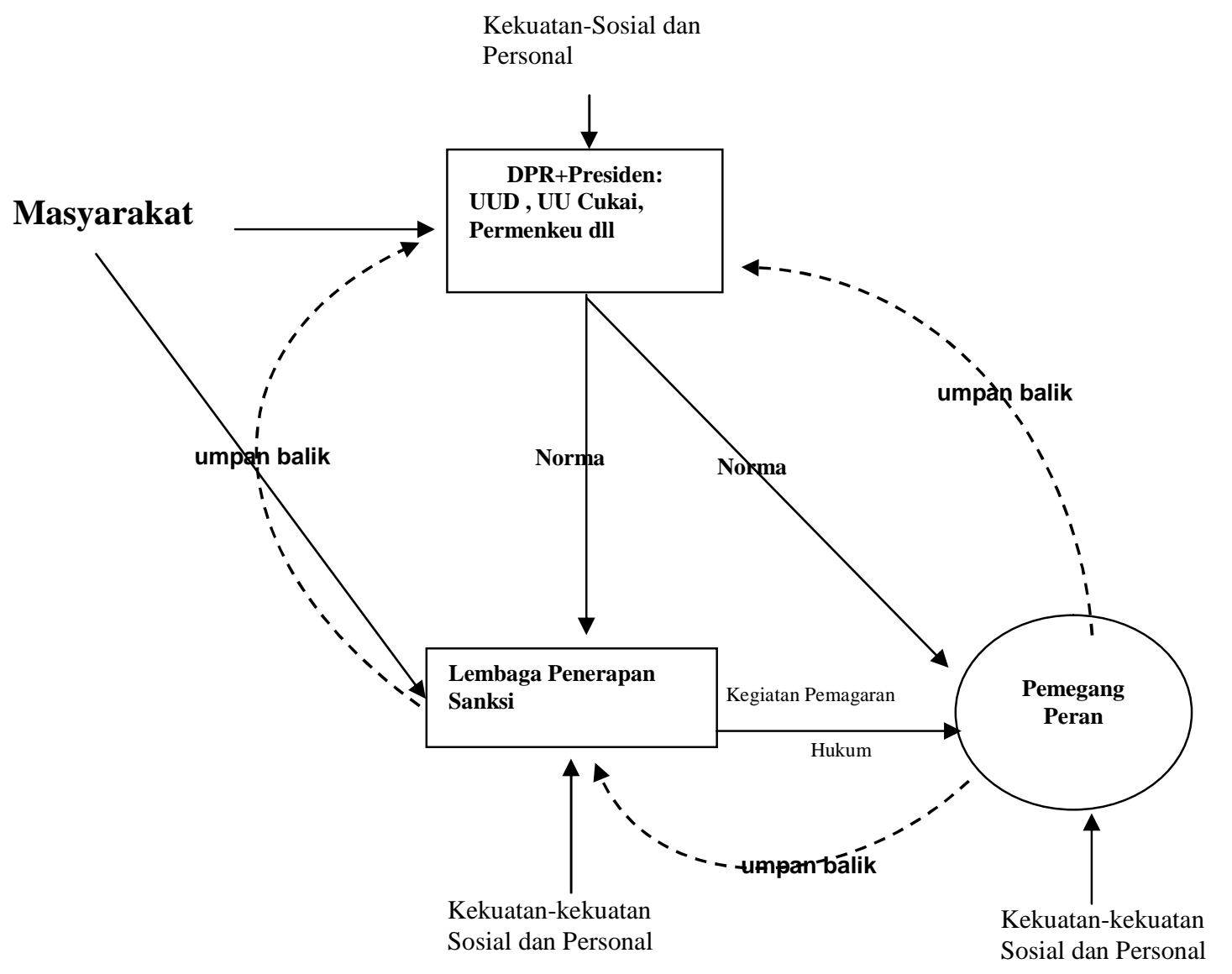

22 Lihat, Lawrence M. Friedman, The Legal System, A Social Science Perspective, Russel Sage Foundation, New York, 1975, hlm. 14-15. 
Selanjutnya dikemukan alasan-alasan pemegang peran bertingkah laku seperti yang sesungguhnya mereka melakukan, berdasarkan norma tertentu yang oleh pembuat peraturan hukum ditunjukan pada mereka, yaitu :

1. Pemegang peran melakukan tingkah laku pilihan dari beberapa alternatif tingkah laku bila mereka memahami tingkah laku itu;

2. Tingkah laku antisipasi dari pihak lain merupakan bagian alternatif pilihan tiap pemegang peran dalam proses pembuatan hukum dan penegakannya;

3. Peranana pemegang peran ditentukan oleh norma-norma yang berlaku;

4. Sistem hukum terdiri dari norma-norma yang diundangkan oleh negara;

5. Setiap peraturan hukum yang ditujukan untuk merubah tingkah laku pemegang peran berarti merubah alternatif pilihan tingkah laku dengan merubah peraturan hukum itu sendiri dan dengan mengubah antispasi tingkah laku oleh pihak-pihak lain;

6. Dalam proses penyelenggaraan hukum, pemegang peran akan bertindak sesuai dengan peraturan hukum berdasar alasanalasan yang disetujui oleh mereka dan tingkah laku yang ditujukan pada mereka dan karena kenyataan bahwa mereka menduduki peran dalam lembaga pengak hukum;
7. dalam proses pembuatan hukum, pemegang peran akan bertindak sesuai dengan peraturan hukum berdasarkan alasan-alasan yang mereka setujui dan karena alasan tingkah laku yang ditujukan pada mereka dar peserta dalam proses penyelenggaraan peran dalam lembaga pembuat hukum; ${ }^{23}$

Dari uraian di atas kiranya dapat dipahami bahwa dalam menelaah hubungan hukum dan kemiskinan tidak dapat dilepaskan dari adanya konsep atau model bekerjanya hukum dalam masyarakat. Bertitik tolak dari batasan model yang tidak dikemukakan oleh Seidman, dapat diketahui dalam peranan hukum dalam mengubah dan mengarahkan perilaku atau pola-pola tingkah laku pemegang peran, dalam hal ini adalah warga masyarakat. Apabila perubahan perilaku ini dapat dilaksanakan maka hukum dalam bekerjanya dapat berfungsi sebagai sarana untuk merekayasa masyarakat (a tool of social Engineering). Dengan demikian pada tingkatan tertentu diharapkan hukum dapat menanggulangi bahkan menghapuskan kemiskinan.

Sementara itu menurut Satjipto Rahardjo, dalam negara Indonesia yang berdasarkan hukum ini, cara-cara hukum memegang peranannya di

${ }^{23}$ Soemitro, Ronny H, Perspektif Sosial Dlam Pemahaman Masalah-Masalah Hukum, (Semarang : Agung Press, 1989), hlm. 83-86. 
bidang manajamen bidang-bidang kehidupan, proses alami, melainkan harus mengikuti jalur seperti sosial dan ekonomi. Cara-cara tersebut pada akhirmnya akan mempertemukan usaha penggulangan kemiskinan dengan hukum. Lebih lanjut Satjipto Rahardjo menunjukan betapa komplek serta rumitnya interaksi masalah hukum dengan masalah sosial, dalam hal ini kemiskinan. Hukum yang diharapkan dapat untuk mencapai tujuan-tujuan yang diingunkan mungkin kurang berhasil untuk mengerjakannya. Bahkan secara sosiologis juga bis ditemukan keadaaa, bagaimana hukum justru merupakan hambatan dalam usaha menanggulangi kemiskinan. Bagi hukum sendiri, apabila segala sesuatunya telah dijalankan sesuai dengan prosedur hukum, maka masalahnya sudah diselesaikan dengan baik. ${ }^{24}$

Penyebaran hukum yang demikian luas ke dalam hampir setiap bidang kehidupan maka hukum itu bisa berfungsi sebagai penghambat dan kendala proses sosial, politik serta ekonomi yang berlangsung dalam masyarakat. $\mathrm{Hal}$ ini dapat dimengerti karena di negara yang berdasarkan hukum ini, setiap warga negara ingin meningkatkan kesejahteraan atau mencapai tingkat kehidupan yang lebih baik, harus berhadapan dengan hukum. Dengan demikian ia tidak dapat bertindak mengikuti

${ }^{24}$ Satjpto Rahardjo, "Memikirkan Hubungan Hukum dan Kemiskinan", Gema Keadilan, No.1 Tahun ke -15, 1991, hlm. 20.

hukum. Pada keadaan tersebut hukum dapat menjadi kendala dan penghambat. ${ }^{25}$

Dengan memperhatikan kenyataan tersebut di muka, apa bila hukum diharapakan untuk bisa dipakai sebagai sarana penaggulangan masalah kemiskinan, maka usaha hendaknya dilakukkan dengan koordinasi, konsolodasi dan kerja sama yang lebih baik di bidang-bidang lain. Penangulangan masalah secara hukum saja tanpa bersama-sama denagn bidang lain niscaya akan mengurangi hasil yang dicapai, bahkan mungkin timbul akibat yang berlawanan. Pada akhirnya dikatakan bahwa penanganan masalah kemiskinan seyogyanya dilakukan secara holistik.

\section{KESIMPULAN}

1. Analisis terhadap hubungan hukum dan kemiskinan tidak dapat dilepaskan dari adanya konsep atau model bekerjanya hukum dalam masyarakat. Bertitik tolak dari batasan model yang tidak dikemukakan oleh Seidman, dapat diketahui dalam peranan hukum dalam mengubah dan mengarahkan perilaku atau polapola tingkah laku pemegang peran, dalam hal ini adalah warga masyarakat. Apabila perubahan

\footnotetext{
$25 \mathrm{Ibid}, \mathrm{hlm} .21$.
} 
perilaku ini dapat dilaksanakan maka hukum dalam bekerjanya dapat berfungsi sebagai sarana untuk merekayasa masyarakat (a tool of social Engineering). Dengan demikian pada tingkatan tertentu diharapkan hukum dapat menanggulangi bahkan menghapuskan kemiskinan.

2. Berdasarkan Pasal $66 \mathrm{~A}$ ayat (1), bagi hasil ini untuk bermacam tujuan yang sudah ditentukan, di antaranya untuk

(1)mendanai peningkatan kualitas bahan baku, (2)pembinaan industri, pembinaan lingkungan sosial,

(3)sosialisasi ketentuan di bidang cukai, serta (4)pemberantasan Barang Kena Cukai (BKC) ilegal.

Pendapatan cukai tentu saja tidak lepas dari jerih payah para karyawan/buruh. Setiap hari sejak subuh para buruh/karyawan sudah berangkat kerja menuju brak-brak rokok untuk membuat lintingan batang per batang. Karena itu, pemerintah daerah perlu memperjuangkan konsep regulasi teknis untuk memikirkan nasib buruh/karyawan. Jika dilihat dari tingkat kesejahteraan, kehidupan para buruh tentu masih belum seluruhnya layak. Karena itu, pemerintah kabupaten perlu memprioritaskan nasib para buruh dalam regulasi di tingkat teknis dalam pengelolaan dana bagi hasil cukai tersebut. Melakukan perbaikan nasib buruh dengan cara: (1) pemberian beasiswa bagi putra-putri buruh, (2) memberikan tambahan penghasilan (tunjangan) bagi para pendidik yang mengelola lembaga pendidikan swasta yang kebanyakan berasal dari keluarga buruh, (3) membangun sarana dan prasarana pendidikan, (4) pemberian pelayanan hibah atau kredit lunak, (5) peningkatan jaminan kesehatan, (6) peningkatan sarana dan prasarana publik yang bermanfaat baik secara langsung atau tidak langsung terhadap produktivitas pabrikpabrik penghasil cukai, serta (7) pemberian subsidi perumahan, dana rehab atau bedah rumah bagi para buruh yang tidak memiliki rumah atau memiliki rumah yang tidak layak huni.

\section{DAFTAR PUSTAKA}

Alwasilah, Chedar, 2002, Pokoknya Kualitatif: Dasar-dasar Merancang dan Melakukan Penelitian Kualitatif, Jakarta: Pustaka Jaya. Ashshofa, Burhan, 1998, Metode Penelitian Hukum hal 20-21, Jakarta: Rineka Karya , dan Hadari Nawaai dan Mimi Martini, 1996, Penelitian Terapan, Yogyakarta: Gadjah Mada University Press. 
Birowo, M.Antonius, 2004, Metode Penelitian Komunikasi: Teori dan Aplikasi, Yogyakarta: Gitanyali.

Black Donald, 1976, The Behaviour of Law, New York: Academic Press.

Bogdan, Robert dan Steven J. Taylor, 1993, Kualitatif: Dasar - dasar Penelitian, Surabaya: Usaha Nasional.

Endraswara, Suwardi, 2006, Metode, Teori dan Teknik Penelitian Kebudayaan, Yogyakarta: Pustaka Widyatama.

Faisal, Sanafiah, 1990, Penelitian Kualitatif: Dasardasar \& Aplikasinya, Malang: Yayasan Asah Asih Asuh

Friedman, Lawrence M., 1975, The Legal System, A Social Science Perspective, New York: Russel Sage Foundation

Guba, Egon G. dan Y. Vonna S. Lincoln. 1994, Handbook of Qualitative Research, London: Sage Publication.

Indarti, Erlyn, "Selayang Pandang Critical Theory, Critical Legal Theory, dan Critical Legal Studies", Majalah Masalah-Masalah Hukum Fak Hukum Undip, Vol. XXXI No. 3 Juli 2002, Semarang.

Moleong, Lexy, 1996, Metodology Penelitian Kualitatif, Bandung: Remaja Rosdakarya Nasution, 1992, Metode Penelitian Naturalistik Kualitatif, Bandung: Tarsito
Rahardjo, Satjipto, 1991, "Memikirkan Hubungan Hukum dan Kemiskinan", Gema Keadilan, No.1 Tahun ke 15

Soemitro, Ronny H, 1989, Perspektif Sosial Dalam Pemahaman Masalah-Masalah Hukum, Semarang: Agung Press

Soemitro, Ronny H, 1989, Studi Hukum dan Kemiskinan, Semarang: Tugu Muda Soemitro, Ronny H, 1985, Studi Hukum dan Masyarakat, Bandung: Alumni Soemitro, Ronny H, 1984, Permasalahan Hukum di Dalam Masyarakat, Bandunng: Alumni.

Sukirno, Sadono, 1985, Ekonomi Pembangunan, Jakarta: Bima Grafika.

Tamanaha Brian Z., 2006, A General J urisprudence of Law and Society, New York: Oxford University Press

Warassih, Esmi, "Peranan Hukum dan Fungsifumngsinya", Masalah -masalah Hukum, No.5 - 19 .

\section{Peraturan Perundang-undangan:}

Undang-Undang Dasar NRI Tahun 1945

UU No. 39 Tahun 2007 Tentang Cukai

Peraturan Menteri Keuangan No. 20/PMK.07/2009 Tentang Penggunaan Dana Bagi Hasil Cukai Hasil Tembakau dan Sanksi Atas Penyalahgunaan Alokasi Dana Bagi Hasil CukaiHasilTembakau. 